\title{
Studies on the Fused Beryllium Chloride-Sodium Chloride System by the Electromotive Force Measurement Method
}

\author{
Tadashi KU RODA and Osamu MA TSUMOTO* \\ Tokyo Institute of Technology, Ookayama, Meguro-ku, Tokyo
}

Received Nov. 11, 1964

\begin{abstract}
The electromotive force of the cell, $\mathrm{Be}(s) / \mathrm{BeCl}_{2}-\mathrm{NaCl}(l) / \mathrm{Cl}_{2}(\mathrm{~g})$, at various concentration of $\mathrm{BeCl}_{2}$, was measured in order to study the nature of the $\mathrm{BeCl}_{2}$ $\mathrm{NaCl}$ system at $400 \sim 500^{\circ} \mathrm{C}$.

The results indicated that the electromotive force was a function of the temperature and the concentration of $\mathrm{BeCl}_{2}$.

The Nernst's plots for the $\mathrm{BeCl}_{2}-\mathrm{NaCl}$ system were different from those supposed for the case of an ideal solution. But, the extrapolated values agreed with those calculated from thermal data, so the cell reaction may be considered to be $\mathrm{Be}(s)+\mathrm{Cl}_{2}(g)=\mathrm{BeCl}_{2}(l)$.

Free energy and the thermodynamic quantities, such as entropy, partial molal free energy, partial molal entropy, activity, activity coefficient, partial free energy and partial entropy were obtained from the measured data. Negative deviations from Raoult's law were observed. These deviations may be due to the formation of complex such as $\mathrm{Na}_{2} \mathrm{BeCl}_{4}$.
\end{abstract}

\section{Introduction}

In the electrolytic preparation of beryllium metal, the mixture of beryllium chloride and sodium chloride is industrially used as the electrolytic bath. Thus knowledge about the properties of this mixture is necessary in order to perform the electrolysis efficiently.

Using cryoscopic method, Furby ${ }^{1)}$ found a eutectic component to exist in this system at the composition of about 0.55 mole fraction of beryllium chloride. Delimarskii ${ }^{2}$ ) measured the decomposition voltage of the eutectic melt of beryllium chloride and sodium chloride. Sheiko ${ }^{3)}$ measured the vapour pressures of beryllium chloride and sodium chloride at various temperatures.

The authors ${ }^{4)}$ measured recently the electromotive force of $\mathrm{Be}(s) / \mathrm{BeCl}_{2}(l)-$ $\mathrm{KCl}+\mathrm{LiCl}$ (eutectic) $(l) / \mathrm{Cl}_{2}(g)$, and made a thermodynamic study of the $\mathrm{BeCl}_{2}-\mathrm{KCl}+\mathrm{LiCl}$ (eutectic) melt. Subsequently, the cell system of $\mathrm{Be}(s) / \mathrm{BeCl}_{2}(l)-\mathrm{NaCl}(l) / \mathrm{Cl}_{2}(g)$ was assembled, and the electromotive force was measured at concentrations between 0.4 and 0.7 mole fraction of beryllium chloride, at $400 \sim 500^{\circ} \mathrm{C}$.

The values measured agreed with those calculated from thermal data ${ }^{5)}$, so the thermodynamic aspects of the fused beryllium chloride and sodium chloride system were discussed. 


\section{Experimentals}

i) Materials Beryllium chloride was prepared by a method reported previously ${ }^{6)}$. Sodium chloride was purified by a recrystallization, and dried at $110^{\circ} \mathrm{C}$.

ii) Apparatus The apparatus is shown in Fig. 1. The cell was an $U$ type pyrex

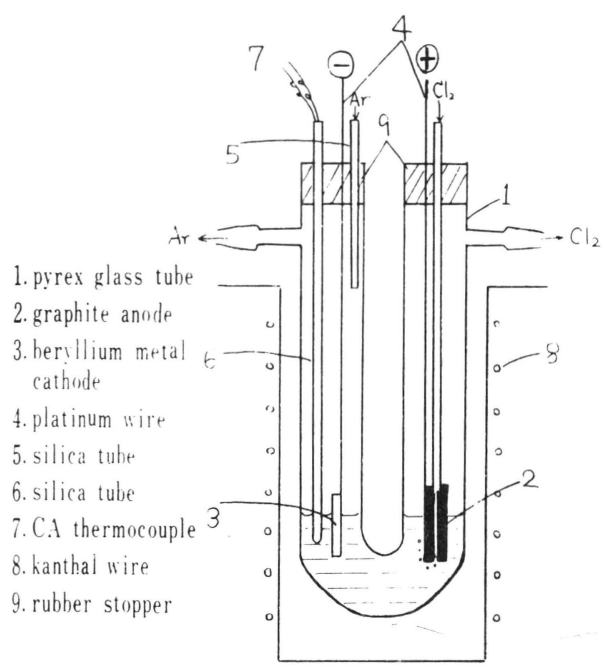

Fig. 1 The apparatus of E.M.F. measurement.

glass tube of $2 \mathrm{~cm}$ in diameter. The anode was a carbon rod, of the type used for spectroscopy, $6 \mathrm{~mm}$ in diameter and $15 \mathrm{~cm}$ long, in the center of which a hole $2 \mathrm{~mm}$ in diameter made to introduce chlorine gas through. The cathode was a beryllium metal rod, $5 \mathrm{~mm}$ in diameter and $1 \mathrm{~cm}$ long. Both electrodes were connected to platinum wires of $1 \mathrm{~mm}$ in diameter.

A Kanthal wire furnace was used for heating the cell. The temperature of the melt was measured by means of calibrated CA thermocouple. Potential-difference measurements were made by a P-21 type potentiometer made by Murayama Elec. Co..

iii) Experimental Results As the melting and boiling points of beryllium chloride are 399 and $482^{\circ} \mathrm{C}$, respectively, the electromotive force was measured in concentrations between 0.4 and 0.7 mole fraction of beryllium chloride at $400 \sim 500^{\circ} \mathrm{C}$.

The relations. ip among the electromotive force(E), the mcle fraction of beryllium chloride $\left(\mathrm{N}_{1}\right)$ and the temperature $\left(\mathrm{T}_{1}\right)$ is shown in Fig. 2. The electromotive force

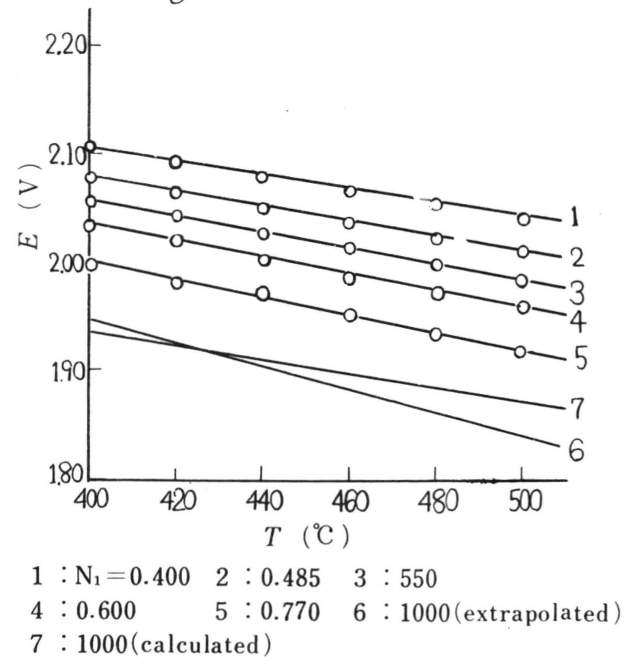

Fig. 2 The relationship among E.M.F. concentration of $\mathrm{BeCl}_{2}$ and temperature.

Table 1 Electromotive Force of $\mathrm{Be}(s) / \mathrm{BeCl}_{2}-\mathrm{NaCl}(l) / \mathrm{Cl}_{2}(g)$ Cell

\begin{tabular}{c|c|l}
\hline \hline$N_{1}$ (mole fraction) & $E t=^{\prime} E_{400}-\mathrm{a}(t-400)(\mathrm{V})$ & Remarks \\
\hline 0.400 & $E_{t}=2,105-6.4 \times 10^{-4}(\mathrm{t}-400)$ & measured \\
0.485 & $E_{t}=2,077-6.7 \times 10^{-4}(\mathrm{t}-400)$ & measured \\
0.550 & $E_{t}=2,057-7.0 \times 10^{-4}(\mathrm{t}-400)$ & measured \\
0.600 & $E_{t}=2,033-7.2 \times 10^{-4}(\mathrm{t}-400)$ & measured \\
0.700 & $E_{t}=1,998-7.9 \times 10^{-4}(\mathrm{t}-400)$ & measured \\
1.000 & $E_{t}=1,924-8.5 \times 10^{-4}(\mathrm{t}-400)$ & extrapolated \\
1.000 & $E_{t}=1,938-6.5 \times 10^{-4}(\mathrm{t}-400)$ & calculated \\
\hline
\end{tabular}


Table 2 Thermodynamic Properties of $\mathrm{BeCl}_{2}-\mathrm{NaCl}$ Melt

$N_{1}=0.400$

\begin{tabular}{|c|c|c|c|c|c|c|c|c|c|c|}
\hline $\begin{array}{l}T \\
\left({ }^{\circ} \mathrm{C}\right)\end{array}$ & $E(\mathrm{~V})$ & $\begin{array}{c}\Delta F_{1} \\
\text { (cal/ } \\
\text { mole) }\end{array}$ & $\begin{array}{c}\bar{F}_{1} \\
\text { (cal/ } \\
\text { mole) }\end{array}$ & $a_{1}$ & $\mathrm{f}_{1}$ & $\begin{array}{c}d E / d T \\
(\mathrm{~V} / \mathrm{deg})\end{array}$ & \begin{tabular}{l}
\multicolumn{1}{c}{$\Delta S_{1}$} \\
(cal/ \\
deg.mole)
\end{tabular} & $\begin{array}{c}\overline{S_{1}} \\
\text { (cal/ } \\
\text { deg. } \\
\text { mole) }\end{array}$ & $\begin{array}{c}\bar{F}_{1}^{\mathrm{E}} \\
\text { (cal/ } \\
\text { deg.mole) }\end{array}$ & $\begin{array}{c}\bar{S}_{\mathrm{i}}^{\mathrm{E}} \\
\text { (cal/) } \\
\text { deg. } \\
\text { mole) }\end{array}$ \\
\hline 400 & 2.105 & $-97,112$ & $-8,362$ & $1.93 \times 10^{-3}$ & $4.82 \times 10^{-3}$ & \multirow{6}{*}{$-6.4 \times 10^{-4}$} & \multirow{6}{*}{-29.52} & \multirow{6}{*}{9.69} & $-7,136$ & \multirow{6}{*}{7.87} \\
\hline 420 & 2.092 & $-96,491$ & $-8,495$ & $2.09 \times 10^{-3}$ & $5.21 \times 10^{-3}$ & & & & $-7,231$ & \\
\hline 440 & 2.081 & $-95,984$ & $-8,802$ & $2.01 \times 10^{-3}$ & $5.03 \times 10^{-3}$ & & & & $-7,503$ & \\
\hline 460 & 2.067 & $-95,338$ & $-8,940$ & $2.16 \times 10^{-3}$ & $5.40 \times 10^{-3}$ & & & & $-7,605$ & \\
\hline 480 & 2.054 & $-94,739$ & $-9,125$ & $2.25 \times 10^{-3}$ & $5.63 \times 10^{-3}$ & & & & $-7,754$ & \\
\hline 500 & 2.041 & $-94,139$ & $-9,310$ & $2.93 \times 10^{-3}$ & $7.33 \times 10^{-3}$ & & & & $-7,902$ & \\
\hline
\end{tabular}

$N_{1}=0.485$

\begin{tabular}{l|l|l|l|l|}
\hline 400 & 2.077 & $-95,808$ & $-7,058$ & $5.11 \times 10^{-3}$ \\
\hline
\end{tabular}

\begin{tabular}{l|l|l|l|l|}
420 & 2.064 & $-95,208$ & $-7,242$ & $5.20 \times 10^{-3}$ \\
\hline 4
\end{tabular}

\begin{tabular}{l|l|l|l|l|l|l|}
440 & 2.051 & $-94,609$ & $-7,427$ & $5.30 \times 10^{-3}$
\end{tabular}

$4602.037-93,963|-7,565| 5.55 \times 10^{-3} \mid$

\begin{tabular}{l|l|l|l|l|l|}
480 & 2.024 & $-93,363$ & $-7,749$ & $5.64 \times 10^{-3}$
\end{tabular}

$1.05 \times 10^{-2}$

$1.07 \times 10^{-2}$

$1.09 \times 10^{-2}$

$1.14 \times 10^{-2}$

$1.16 \times 10^{-2}$

\begin{tabular}{l|l|l|l|l|l}
500 & 2.010 & $-92,712$ & $-7,888$ & $5.89 \times 10^{-3}$ \\
\hline
\end{tabular}

$1.21 \times 10^{-2}$

\begin{tabular}{|c|c|c|}
\hline \multirow{6}{*}{8.30} & $-6,091$ & \multirow{6}{*}{6.86} \\
\hline & $-6,245$ & \\
\hline & $-6,403$ & \\
\hline & $-6,512$ & \\
\hline & $-6,667$ & \\
\hline & $-6,777$ & \\
\hline
\end{tabular}

$N_{1}=0.550$

\begin{tabular}{l|l|l|l|l|}
\hline 400 & 2.057 & $-94,885$ & $-6,135$ & $1.02 \times 10^{-2}$ \\
420 & 2.043 & $-94,240$ & $-6,244$ & $1.07 \times 10^{-2}$ \\
440 & 2.028 & $-93,548$ & $-6,366$ & $1.12 \times 10^{-2}$ \\
460 & 2.015 & $-92,948$ & $-6,550$ & $1.11 \times 10^{-2}$ \\
480 & 2.001 & $-92,302$ & $-6,688$ & $1.15 \times 10^{-2}$ \\
500 & 1.987 & $-91,656$ & $-6,827$ & $1.18 \times 10^{-2}$ \\
\hline
\end{tabular}

\begin{tabular}{l|l|l|l|l}
$1.86 \times 10^{-2}$ & & & & $-5,334$ \\
$1.95 \times 10^{-2}$ & & & & $-5,418$ \\
$2.04 \times 10^{-2}$ & $-7.0 \times 10^{-4}$ & -32.29 & 6.92 & $-5,520$ \\
$2.03 \times 10^{-2}$ & & & & $-5,678$ \\
$2.09 \times 10^{-2}$ & & & & $-5,792$ \\
$2.15 \times 10^{-2}$ & & & & $-5,907$ \\
\hline
\end{tabular}

$N_{1}=0.600$

\begin{tabular}{l|l|l|l|l|}
\hline 400 & 2.033 & $-93,778$ & $-5,028$ & $2.33 \times 10^{-2}$ \\
420 & 2.020 & $-93,179$ & $-5,183$ & $2.32 \times 10^{-2}$ \\
440 & 2.003 & $-92,394$ & $-5,212$ & $2.53 \times 10^{-2}$ \\
460 & 1.987 & $-91,656$ & $-5,258$ & $2.71 \times 10^{-2}$ \\
480 & 1.975 & $-91,103$ & $-5,489$ & $2.56 \times 10^{-2}$ \\
500 & 1.961 & $-90,457$ & $-5,628$ & $2.57 \times 10^{-2}$ \\
\hline
\end{tabular}

\begin{tabular}{l|l}
$3.89 \times 10^{-2}$ & \\
$3.87 \times 10^{-2}$ & \\
$4.22 \times 10^{-2}$ & $-7.2 \times 10^{-4}$ \\
$4.51 \times 10^{-2}$ & \\
$4.27 \times 10^{-2}$ & \\
$4.30 \times 10^{-2}$ & \\
\hline
\end{tabular}

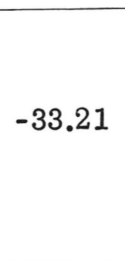

\begin{tabular}{l|l} 
& $-4,350$ \\
6.00 & $-4,484$ \\
$-4,494$ \\
$-4,520$ \\
$-4,731$ \\
$-4,850$
\end{tabular}

4.99

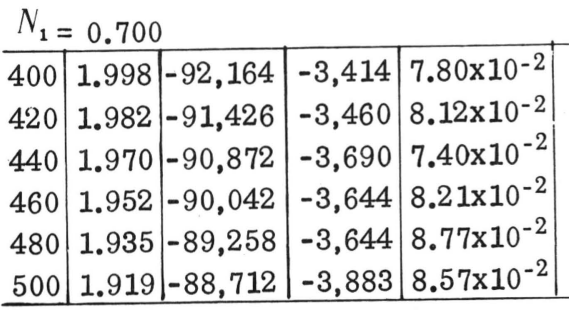

$1.11 \times 10^{-1}$
$1.16 \times 10^{-1}$
$1.06 \times 10^{-1}$
$1.17 \times 10^{-1}$
$1.25 \times 10^{-1}$
$1.22 \times 10^{-1}$

\begin{tabular}{c|c|c|c|} 
& & & $-2,937$ \\
$-8.5 \times 10^{-4}$ & -39.21 & 2.77 & $-2,968$ \\
& & & $-3,184$ \\
& & & $-3,124$ \\
& & & $-3,335$ \\
\hline
\end{tabular}

2.31

$N_{1}=1.000$

\begin{tabular}{l|l|l|}
\hline 400 & 1.924 & $-88,750$
\end{tabular}

\begin{tabular}{l|l|l|l}
420 & 1.907 & $-87,996$
\end{tabular}

\begin{tabular}{l|l|l|}
440 & 1.890 & $-87,182$
\end{tabular}

\begin{tabular}{l|l|l|l}
460 & 1.873 & $-86,398$
\end{tabular}

\begin{tabular}{l|l|l|}
480 & 1.856 & $-85,614$ \\
\hline
\end{tabular}

\begin{tabular}{ll|l|l|}
500 & 1.839 & $-84,829$
\end{tabular}

\begin{tabular}{l|l|l|}
0 & 1 & 1 \\
0 & 1 & 1 \\
0 & 1 & 1 \\
0 & 1 & 1 \\
0 & 1 & 1 \\
0 & 1 & 1 \\
\hline
\end{tabular}

\begin{tabular}{|l|l|l|l}
\hline$-7.9 \times 10^{-4}$ & -36.44 & 0 & 0 \\
& & & 0 \\
& & & 0 \\
& & & 0 \\
\hline
\end{tabular}


at several concentrations of beryllium chloride was a function of the temperature as shown in Table 1.

The extrapolated values of the obtained curves agreed with the values calculated from thermal data within a difference of about $15 \mathrm{mV}$ at $400^{\circ} \mathrm{C}$ and about $30 \mathrm{mV}$ at $500^{\circ} \mathrm{C}$.

\section{Discussion}

The Nernst's plots for the fused beryllium chloride and sodium chloride system are shown in Fig. 3. The difference be-

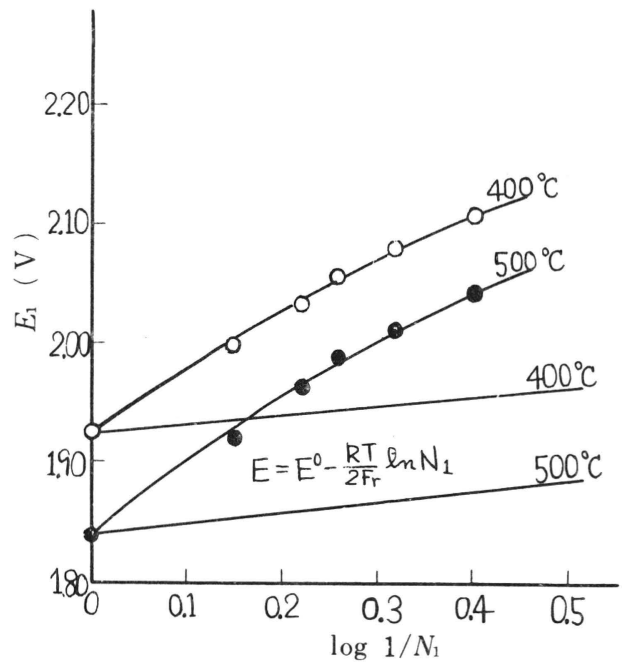

Fig. 3 Nernst's plot for $\mathrm{BeCl}_{2}-\mathrm{NaCl}$ melt

tween the measured values and the calculated values for the ideal solution is so large that the cell reaction can not be considered to be a two electrons reaction, such as $\mathrm{Be}(s)+\mathrm{Cl}_{2}(g)=\mathrm{BeCl}_{2}(l)$. But, the values calculated from thermal data agreed with the extrapolated values of the curves obtained, so the cell reaction seems to be a two electrons reaction as indicated above.

As the measured electromotive forces were shown to agree well with the values obtained from thermal data, the related thermodynamic quantities of beryllium chloride in the melt were calculated.
The results are listed in Table 2, where suffix 1 indicates $\mathrm{BeCl}_{2}$, E-measured electromotive force, $\Delta F_{1}$-free energy, $\bar{F}_{1}$-partial molal free energy, $\Delta S_{1}$-entropy, $\bar{S}_{1}$-partial molal entropy, $a_{1}$-activity and $f_{1}$ is the activitv coefficient. $\bar{F}_{1}^{\mathrm{E}}$ and $\bar{S}_{1}^{\mathrm{E}}$ are excess partial molal free energy and excess partial molal entropy, respectively.

The relationship between $a_{1}$ and $N_{1}$ is shown in Fig. 4. The activity $a_{1}$ was very small and indicated a large negative deviations from Raoult's law.

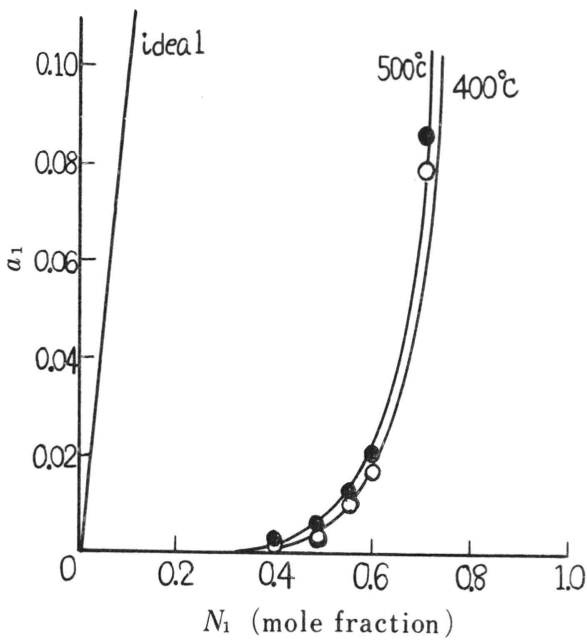

Fig. 4 Relationship between $a_{1}$ and $N_{1}$.

The relationship between $-\bar{F}_{1}$ and $\log$ $1 / N_{1}$ is shown in Fig. 5. The measured

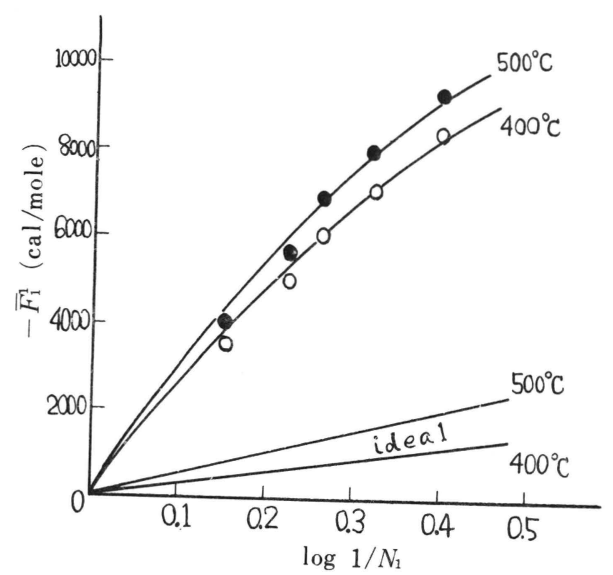

Fig. 5 Relationship between $\bar{F}_{1}$ and $\log 1 / N_{1}$. 
Table 3 Energy of Mixing ( $\mathrm{Kcal} / \mathrm{mole}$ )

\begin{tabular}{|c|c|c|c|}
\hline$N_{1 \text { (mole fraction })}^{T\left({ }^{\circ} \mathrm{C}\right)}$ & 400 & 460 & 500 \\
\hline 0.400 & $-91.82(-14.82 R T)$ & $-21.13(-14.50 R T)$ & $-21.95(-14.29 R T)$ \\
\hline 0.485 & $-22.99(-17.19 R T)$ & $-24.57(-16.87 R T)$ & $-25.57(-16.65 R T)$ \\
\hline 0.550 & $-26.28(-19.65 R T)$ & $-27.97(-19.20 R T)$ & $-29.10(-18.95 R T)$ \\
\hline 0.600 & $-27.19(-20.33 R T)$ & $-28.25(-19.40 R T)$ & $-30.32(-19.74 R T)$ \\
\hline 0.700 & $-32.63(-24.40 R T)$ & $-34.71(-23.83 R T)$ & $-37.06(-24.13 R T)$ \\
\hline
\end{tabular}

values also show a large deviation from Raoult's law.

The relationship between $\bar{S}_{1}$ and $\log$ $1 / N_{1}$ is shown in Fig. 6. The measured values showed a large deviations from a curve for an ideal solution.

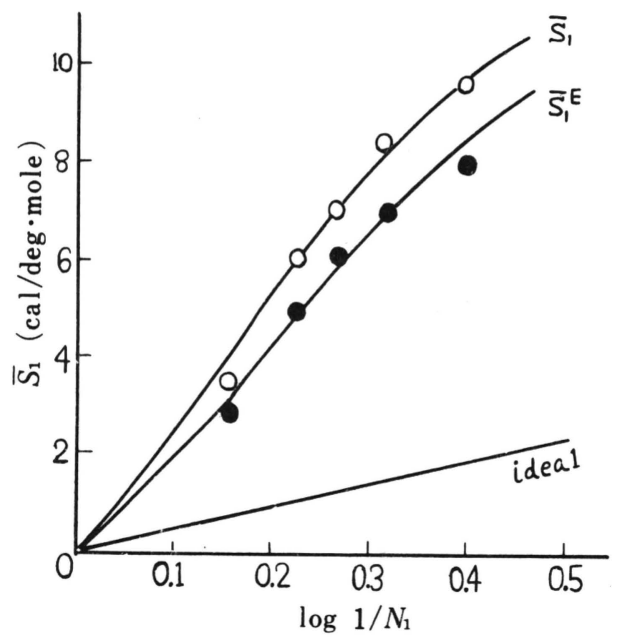

Fig. 6 Relationship between $\bar{S}_{1}$ and $\log 1 / N_{1}$

If the fused beryllium chloride and sodium chloride system is a regular solution, $f_{1}$ and an energy of mixing $w_{12}$ are related by equation (1).

$$
f_{1}=\exp \left\{\left(w_{12} / R T\right)\left(1-N_{1}\right)^{2}\right\}
$$

so, $w_{12}$ is given by

$$
w_{12}=\left\{R T /\left(1-N_{1}\right)^{2}\right\} \ln f_{1}
$$

The obtained values of $w_{12}$ are shown in Table 3. In the experimental results, $w_{12}$ is $-15 \sim-24 R T$, so the solution is not always a regular solution.

Furby l) reported the existence of a complex, such as $\mathrm{Na}_{2} \mathrm{BeCl}_{4}$, between beryllium chloride and sodium chloride, by a cryoscopic study.

As the values of $w_{12}$ are negative and large, the fused beryllium chloride and sodium chloride system may be stabilized by the formation of a complex such as $\mathrm{Na}_{2} \mathrm{BeCl}_{4}$ in the melt.

The relationship between the excess partial free energy $\left(N_{1} F_{1}^{-E}\right)$ and $N_{1}$ is shown in Fig. 7. The curves prove the occurrence

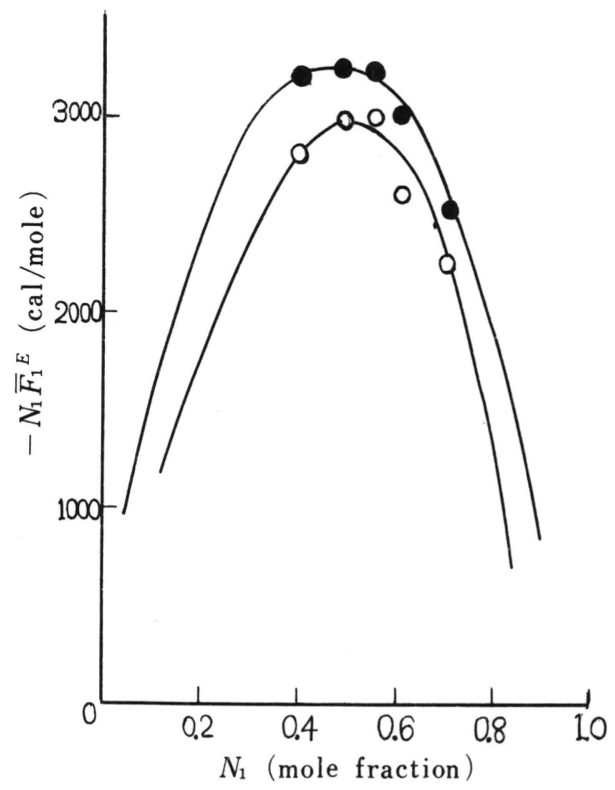

Fig. 7 Relationship between $N_{1} \bar{F}_{1}^{\mathrm{E}}$ and $N_{1}$. 
of a chemical interaction between the components. ${ }^{\text {) }}$ This means that the stabilization of the melt was due to the formation of a complex.

From the results of these studies, it is expected that a complex between beryllium chloride and sodium chloride is formed. So, the negative deviation from Raoult's law may be due to the stabilization of the solution by the formation of a complex such as $\mathrm{Na}_{2} \mathrm{BeCl}_{4}$.

\section{Summary}

(1) The electromotive force of the cell $\mathrm{Be}(s) / \mathrm{BeCl}_{2}-\mathrm{NaCl}(l) / \mathrm{Cl}_{2}(\mathrm{~g})$ was measured in the range of $0.4 \sim 0.7$ mole fraction of $\mathrm{BeCl}_{2}$ at $400 \sim 500^{\circ} \mathrm{C}$. The electromotive force was a function of temperature and of the concentration of beryllium chloride.

(2) The Nernst's plots for the $\mathrm{BeCl}_{2}$ $\mathrm{NaCl}$ (l) system differs from the experimental curves. But the extrapolated values from the obtained curves agreed with the values calculated from thermal data, so the cell reaction may be $\mathrm{Be}(s)+$ $\mathrm{Cl}_{2}(g)=\mathrm{BeCl}_{2}(l)$.
(3) Free energy and the related thermodynamic quantities were obtained from the measured values. Negative deviations from Raoult's law were observed. These deviations may be due to the formation of a complex such as $\mathrm{Na}_{2} \mathrm{BeCl}_{4}$.

Literature:

1) E. Furby, K. L. Wilk inson, J. Inorg. \& Nuclear Chem. 14, 123 (1960).

2) I. U. Delimarskii, I. N. Sheiko, Ukr. Khim. Zh. 23, 713 (1957).

3) I. N. Sheiko, U. G. Feschckenko, Ukr. Khim. Zh. 28, 478 (1962).

4) T. Kuroda, O. Matsumoto, Denki-Kagaku 31, 688 (1963).

5) A. Glassner, $A N L 5750$ (1957).

6) T. Kuroda, O. Matsumoto, Denki-Kagaku 31,338 (1963).

7) I. U. Delimarskii, B. F. Markov, "Electrochemistry of Fused Salt" P.117 (1961), The Sigma Press. 